\title{
EFFECTS OF MOISTURE CONDITIONS ON THE SMALL MAMMAL COMMUNITIES OF FLOODPLAIN FORESTS IN SOUTH MORAVIA (CZECH REPUBLIC)
}

\author{
UTJECAJ VLAŽNOSTI NA POPULACIJE SITNIH SISAVACA \\ U POPLAVNIM ŠUMAMA JUŽNE MORAVSKE (ČEŠKA REPUBLIKA)
}

\author{
Josef SUCHOMEL', Marta HEROLDOVÁ², Pavel HADAŠ³ ${ }^{3}$ Jan ZEJDA4
}

\begin{abstract}
Summary
Changes of the moisture regime and its influence on the dominance of selected species of small mammal communities were studied in floodplain forests in southern Moravia (river Dyje). In period of typical floodplain regime characterized by groundwater table fluctuation (1968-1972, with high groundwater table level or floods in spring) dominance of Apodemus flavicollis (Mel.) was 42\%, Myodes glareolus (Schreb.) 33\% and Sorex araneus L. 15\% of the total small mammal communities. In period 1982-1987 after cessation of floods by river regulation, rapid groundwater drop and changes in the herb layer, the dominance of Apodemus flavicollis and Myodes glareolus increased. Also the dominance of Apodemus sylvaticus (L.) increased, but that of Sorex araneus collapsed. Further revitalization measures were applied by systems of channels supplying the water to root system of forest trees but not to the herb layer. In 2002-2006 decreasing moisture condition further influenced the dominance of Apodemus flavicollis reaching mean dominance $62 \%$, Myodes glareolus dominance decreased to $20 \%$ and that of Sorex araneus remain to be low. All estimated changes were correlated with moisture regime changes and were significant. Thus the changes in the forest moisture regime significantly affect the community of small terrestrial mammals.
\end{abstract}

KEY WORDS: floodplain forest, biosphere reserve, moisture regime, small terrestrial mammals, dominance

\section{INTRODUCTION}

UVOD

By Moran et al. (2008) the science of ecohydrology is characterized by feedbacks, gradual trends and extreme events that are best revealed with long-term experimental studies of hydrological processes and biological communities. We were taken the opportunity to study lowland forest ecosystem together with its water supply changes in three distant periods in the Lower Morava Biosphere Reserve (Czech Republic). These were included in the UNESCO Man and the Biosphere (MAB) Programme (Moran et al. 2008). The core area of the Morava-Dyje riverine landscape, covered by periodically flooded floodplain forest is one of the most productive ecosystems in the world (Zejda 1991). The Morava-Dyje riverine landscape is one of the last regions in Europe where traditional land use has secured a rich biodiversity. Moisture regime of floodplain forests (high water

\footnotetext{
'Ass. Prof. Josef Suchomel, PhD., Department of Zoology, Fisheries, Hydrobiology and Apiculture, Faculty of AgriSciences, Mendel University in Brno, Zemědělská 1 , 61300 Brno, Czech Republic

${ }^{2}$ Ass. Prof. RNDt. Marta Heroldová, PhD., Institute of Forest Ecology, Faculty of Forestry and Wood Technology, Mendel University in Brno, Zemědělská 3, 61300 Brno, Czech Republic

${ }^{3}$ RNDt. Pavel Hadaš, PhD., Veselská 31, Strážnice, 696 62, Czech Republic

${ }^{4}$ Ass. Prof. Jan Zejda Dr. sc., Tábor 48d, Brno, 602 00, Czech Republic
} 
table, periodical floods etc.) created specific life conditions for communities of plants and animal species. However, regulation of the two rivers and construction of water networks during the 1970s have changed the water regime of forests. Changes in moisture conditions subsequently caused changes in characteristics of biocenosis. The most rapid and most flexible response was found in the herb layer, where the total biomass was reduced considerably (Vašíček 1991). The structure of the herb layer was shifted to drier herb communities which subsequently influenced insect communities (decreased species richness and diversity; Kř́istek 1991).

The community of small terrestrial mammals in a periodically flooded floodplain forest is characterized by high productivity (Zejda 1991). Although dynamic moisture regime of floodplain forests (high water table, periodical floods etc.) creates specific life conditions for communities of plants and animal species, most dominant species are well adapted to this environment. Small mammal individuals are forced to survive in refugia and the non-flooding parts during floods. Short period of inundation can be possibly survived by certain species in vegetation above the water level (Wijnhoven et al. 2005). Arboreal activity is known in all species of central European mice and the bank vole (Holišová 1969). The negative effect of flooding on their populations is relatively minor (Zejda 1976; Jacob 2003). The indirect effect of floods - which is the high primary production following the floods - has positive effects on their population density (Zejda 1991). The small mammal species (Rodentia, Eulipotyphla) are well known to be responsive to the variation in moisture in terms of changes in community structure and their monitoring can therefore be of bioindicative significance (Wijnhoven et al. 2005; 2006; Zejda 1976; 1985; 1991; Zhang et al. 2007).

In the presented study, we bring the long-term assessment of the effect of moisture conditions on the dominance structure of small mammals in floodplain forests of southern Moravia (Czech Republic). Based on detailed data from three periods (1968-1972, 1982-1987, and 2002-2006) covering a span of over 30 years, we highlight the influence of the moisture regime on the small mammal assemblage in a floodplain forest. We show that under lowered moisture conditions and reduced abundance of insects, the insectivorous mammals are among the most affected species, whereas the rodent community appears to be more resistant and respond less dramatically.

\section{MATERIAL AND METHODS} MATERIJALI I METODE

The studied habitats are part of the largest preserved ecosystem of floodplain forests in central Europe. The climate of the locality is warm, dry to subhumid, with a mean annual air temperature of $9^{\circ} \mathrm{C}$ and a mean annual precipitation of $524 \mathrm{~mm}$ (Vašíček \& Pivec 1991). The study area (120 ha of old forest) was situated near the town of Lednice at $164 \mathrm{~m}$ a.s.l. with coordinates $48^{\circ} 48^{\prime} 30^{\prime \prime} \mathrm{N}, 16^{\circ} 47^{\prime} 05^{\prime \prime} \mathrm{E}$. This is a Research and monitoring site of Mendel University (Brno), part of the International Long-Term Ecological Research (ILTER) network. The study plots were located in a seminatural forest characterized by a group of forest types UlmetoFraxinetum carpineum. It was originally a commercial forest (hard-wooded broadleaved stand about 100 years old in 1965 - at the beginning of monitoring), which was excluded from forest management and left as an experimental area for studying natural processes in forest ecosystems. Consequently, the forest is of natural character representing long term stabilized tree stands with minimal changes in tree stratum. The dominant species are: pedunculate oak (Quercus robur L.), common ash (Fraxinus excelsior L.), black poplar (Populus nigra L.), large-leaved linden (Tilia platyphyllos Scop.), and field maple (Acer campestre L.). In the shrub layer, following species occur most frequently: dogwood (Cornus sanguinea L.), European evonymus (Euonymus europaeus L.), European elder (Sambucus nigra L.), and also young trees of pedunculate oak, large-leaved linden, and field maple.

Herb layer of floodplain forests in the alluvium of the Dyje river were influenced by changes in the water regime as a result of constructing flood-control protection measures since 1972 (the absence of natural floods, decrease of the groundwater table). During the 1970s and 1980s, the forest was insufficiently supplied by water and began to dry. Herb layer composition changed during the study period from dominant Carex acutiformis Ehrh. and Rubus caesius L. to dominant Impatiens parviflora DC., Circaea lutetiana L. and Galium aparine L. The other common species were Urtica dioica L., Ajuga reptans L., Glechoma hederacea L. and Deschampsia cespitosa (L.) (see Penka et al. 1985; 1991 for detailed data).

Since the 1990s, forest revitalization measures, aimed at water regime improvement in the study area were undertaken. These resulted only in replenishment of groundwater level by means of channels (no periodically flooded forest), thus improving the water condition for deeply rooted trees of the forest (Hadaš 2003) having no effect on any changes in other forest environment. The long-term changes in water regime provide us with opportunities to investigate ecological changes in the floodplain forest and obtain data, which are necessary for its well-informed management.

Dominance of small mammals (Apodemus flavicollis AF; A. sylvaticus AS; Myodes (Clethrionomys) glareolus MG; Sorex araneus SA) was studied in three time periods (period 1: 1968-1972 period 2: 1982-1987, and period 3: 20022006) under various moisture conditions (i.e. $\mathrm{AF} 1, \mathrm{AF} 2$ and AF3 means dominance of Apodemus flavicollis in period 1, 
2 and 3; same hold for other species, see Fig. 2) and was expressed as Simpson index of dominance:

$$
\mathrm{D}_{\mathrm{S}}=\sum_{i=1}^{i=n}\left(\frac{N i}{N}\right)^{2}(\text { Odum 1977) }
$$

In total, 2708 small mammal individuals of 9 species were documented on the study site. For this study, data were collected under criteria as to have sufficient spatial coverage to represent the dynamics of small mammal dominance of the given range or forest; the measurement protocols were consistent on the basis of the effort and methodology (snap trapping in spring and autumn; see Zejda 1991 for details). Rodents were represented by 6 species: yellow-necked mouse (Apodemus flavicollis), wood mouse (Apodemus sylvaticus), bank vole (Myodes glareolus), common vole (Microtus arvalis), European pine vole (Microtus subterraneus, and house mouse (Mus musculus). Insectivores included 3 species: common shrew (Sorex araneus), European pygmy shrew (S. minutus), and European water shrew (Neomys fodiens). For statistical analysis, only the data on yellownecked mouse, wood mouse, bank vole and common shrew, as sufficient number of individuals, were used. For all species under study and year we calculated mean dominance index D (in \%) for spring and autumn communities. Differences in dominance between various time periods of particular small mammal species were calculated by One-way Anova in Statistica for Windows.

We assessed the long-term changes in relation to the moisture regime (MR) of the floodplain ecosystem. Variation in floodplain MR was measured by means of 2 variables: (1) the flow regime (FR) of the Dyje river and (2) the moisture balance (MB; Hadaš 2003). The FR is expressed by the sum of mean monthly discharges of the Dyje river for the period March-May and June-September in the area of floodplain forests in the section from Nové Mlýny to Břeclav. Moisture balance $(\mathrm{MB})$ is based on the following relation (Možný 1993):

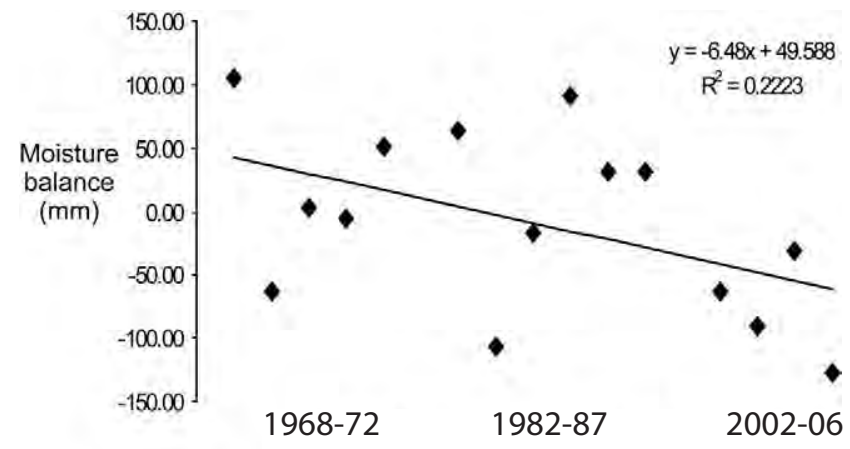

Fig. 1. Dynamic of calculated moisture balance (in $\mathrm{mm}$ ) during the years of research.

Graf 1. Dinamika izračunate ravnoteže vlage (u mm) tijekom godina istraživanja.
$M B=\left(R_{a}-R_{n}\right)-\left(E T P_{a}-E T P_{n}\right)$, where $R_{a}$ is the monthly total of precipitation in the given year in $\mathrm{mm}, \mathrm{R}_{\mathrm{n}}$ is the longterm total of precipitation in the given month, $\mathrm{ETP}_{\mathrm{a}}$ is the monthly total of potential evapotranspiration in the given year in $\mathrm{mm}, \mathrm{ETP}_{\mathrm{n}}$ is the long-term total of potential evapotranspiration in the given month in $\mathrm{mm}$. The sum of MB is calculated for the period April to September. The potential evapotranspiration $\left(\mathrm{ETP}_{\mathrm{a}}, \mathrm{ETP}_{\mathrm{n}}\right)$ is derived using an indirect method according to Thornthwait (Nosek 1972). Moisture balance showed decreasing tendency in time (see Fig. 1). Its dynamic was also influenced by summer „flash floods” but these time limited floods have not permanent effect on the plant and animal community as periodic spring floods.

We calculated the coefficient of correlation $(r)$ to describe the relationship between the MR and the spring and autumn species dominance of small terrestrial mammals of floodplains for particular years. The significance of the dependence is calculated according to simple linear regression. To assess the combined effect of the FR and MB in the growing season, multiple regression analysis was used. Periods were evaluated from a derived multiple linear regression model (MLRM) and significance value was obtained.

\section{RESULTS}

REZULTATI

Changes in dominance were monitored in yellow-necked mouse as its population steadily increases its proportion in studied communities (Fig. 2). However, a marked increase in dominance was also noted in wood mouse. From the previous fragmentary occurrence in the 1970s, it increased its dominance after changes in the water regime in the 1980s $(\mathrm{F}=9.82 ; \mathrm{p}<0.01$ between populations in period 1 and 2 ; Fig. 2). Later on, a decrease in the percentage proportion occurred evidently at the expense of the increase of a more dominant and aggressive yellow-necked mouse population. In bank vole, changes in the water regime became evident by the decline of dominance (Fig. 2). The most marked changes were in insectivores. The highly dominant species, common shrew, showed a rapid fall to roughly $1 \%$ of dominance after regulation measures have been introduced $(\mathrm{F}=10.49 ; \mathrm{p}<0.01$ between populations in period 1 and 2; Fig. 2).

During the first period from 1968 to 1972, the springtime correlation of MR with small mammal species dominance was significantly high only in bank vole $(r=0.67$; significance value was 0.59$)$. During the period under water regulation (2002-2006) in spring, the bank vole dominance was also positively influenced by MR $(r=0.86)$ and FR dynamics in the Dyje river $(r=0.87$, significance value was 0.82 ). The lowland drying influenced the gradual decreasing dominance of the species.

The summer dominance of common shrew (1968-1976) highly correlates with the FR dynamics $(r=0.91$; signifi- 


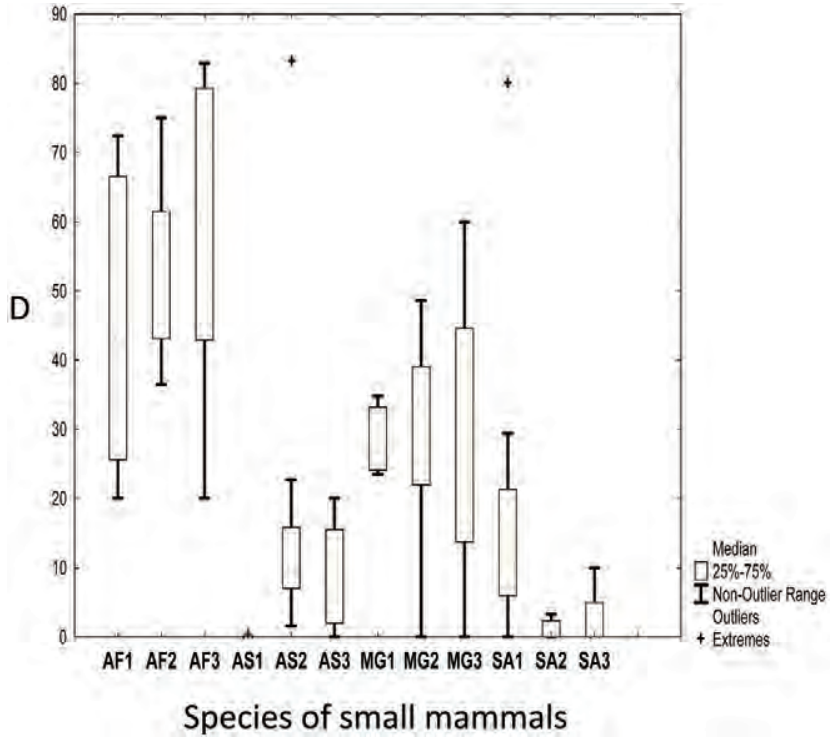

Fig. 2. Dominance of small mammals (Apodemus flavicollis AF; A. sylvaticus AS; Myodes (Clethrionomys) glareolus MG; Sorex araneus SA) in three time periods (period 1: 1968-1972 period 2: 1982-1987, and period 3: 2002-2006) under various moisture conditions (i.e. AF1-3 dominance of Apodemus flavicollis in period 1, 2 and 3; same hold for other species).

Graf 2. Zastupljenost sitnih glodavaca (Apodemus flavicollis AF; A. sylvaticus AS; Myodes (Clethrionomys) glareolus MG; Sorex araneus SA) u tri vremenska perioda (period 1: 1968-1972 period 2: 1982-1987, i period 3: 2002-2006) pod različitim uvjetima vlažnosti (npr. AF1-3 dominantnost Apodemus flavicollis u periodu 1, 2 i 3; isto vrijedi i za druge vrste).

cance value was 0.59). Decrease of the water level in the Dyje river caused the decrease of the dominance of common shrew and vice versa. Dynamics of the FR is not influenced by the flooding regime.

Wood mouse responded well to changes in the MR during summer and at the beginning of autumn during the period 1982-1987. This species shows high indirect dependence on changes in the FR during summer $(r=-0.77)$, which is also influenced by the decrease of water level in the Dyje river $(r=-0.81$; significance value was 0.74$)$. The high soil moisture (high water table in forests influenced by the high flow of the Dyje river) reduced the dominance of wood mouse and drying of the lowland positively influenced its dominance.

To evaluate the aggregate effect of the FR and MB in the growing season, a MLRM was used for the period 19821987. It follows that the model is able to explain the dominance of wood mouse according to the coefficient of determination of $67.9 \%(r=68)$ on the basis of mean monthly flows and MB during the summer season.

Dominance $($ wood mouse $)=$

$$
19.50-0.07 \cdot \text { monthly flow }+0.0179 \cdot \mathrm{MB}
$$

It means that the FR and $\mathrm{MB}$ can explain $67.9 \%$ changes in the wood mouse population dominance. The proportion of other effects (factors) influencing the dominance amounts to $32.1 \%$. The dominance of this species increases with the decline of flow during the summer season. Similar behavior according to the multiple regression function can be also noted in yellow-necked mouse in the spring season of the period 2002-2006.

Dominance $($ yellow-necked mouse $)=$ $-1.93 \cdot$ monthly flow $+3.69 \mathrm{MB}+553.38$.

The derived regression model is able to explain the yellownecked mouse dominance of $80.7 \%(r=0.81)$ on the basis of mean monthly flow and $\mathrm{MB}$ during the spring season 2002-2006. More than $80 \%$ of the yellow-necked mouse population prefers dry sites without the effect of floods.

According to the regression model, opposite behavior expressing the dependence of the dominance of bank vole on the FR and the MB in the growing season is shown in the period 2002-2006

Dominance $($ bank vole $)=$

$$
0.42 \cdot \text { monthly flow }-0.39 \cdot \mathrm{MB}-65.55 \text {. }
$$

The model can explain changes in the dominance from $76.6 \%(r=0.77)$ that is, with the increase of the FR and improvement of $\mathrm{MB}$ the dominance of bank vole increases. Improvement in the $\mathrm{MB}$ is affected by the increase of precipitation and decline of air temperature in the floodplain alluvium and higher water level in the Dyje river. The species prefers sites of higher moisture where the value of the FR factor is slightly higher than the factor of MB.

During the spring season of 2002-2006, the behavior of common shrew showed dependence on the FR and the MB aggregate effect.

Dominance $($ common shrew $)=$

$$
0.39 \cdot \text { monthly flow }-0.87 \cdot \mathrm{MB}-103.77 \text {. }
$$

The derived regression model confirmed $62.9 \%$ of dominance changes to be influenced by MB. Generally, this species prefers humid sites, which are temporarily slightly moistened by local precipitation.

\section{DISCUSSION RASPRAVA}

Changes in the MR, namely in the level of the water table and the elimination of regular floods together with associated changes in the phytocoenosis and zoocoenosis of the floodplain forest ecosystem affected the dominance of the small terrestrial mammals. Three periods were compared in this study. The first period is from 1968 to 1972 (Zejda 1976) when flood plain forest was influenced by periodical flows, the second period is from 1982 to 1985 (Zejda 1991) when floods ceased, and the third is from 2002 to 2006 (Suchomel \& Heroldová 2004; Suchomel et al. 2012) after revitalization measures were applied. Even though the data are merely correlative in nature, we believe that they reflect 
a real causal relationship between water regime and structure of small mammal assemblages.

After floods regulation, changes in the soil moisture, microclimate, herb layer composition, and in the community of invertebrates (Vaňhara 1986) affected the number of insectivores. For example, the species richness and densities of Carabidae and Arachnoidea decreased (Křístek 1991). These groups create the important source of food for Sorex species (Kolibáč 1995). The other protected insectivorous species Neomys fodiens disappeared from the plots (Zejda 1991). Sorex sp. are the dominant species in the Natural Reserve Jursky Sur - the largest swampy alder forest in Central Europe which is flooded 5 month of the year usually. By Pachinger (1982) and Pachinger \& Haferkorn (1998), high level of moisture was positively influencing the dominance of insectivores.

Many plants requiring high moisture content declined both in numbers and tissue production. The greatest decline was that of the previously dominant Glechoma hederacea. Its dominance changed from almost $42 \%$ of the herb layer cover at the initial stage to $5 \%$ at time of flood regulation (Vašíček 1991). G. hederacea was, for example, one of the main diet items of the overcrowded population of bank vole (mean volume over 25\%, Holišova 1971). Under conditions of the flooded forest, population of bank vole became regularly overcrowded (Zejda 1976). Under changed conditions, intervals of outbreaks prolonged similar to in the drier broadleaved forests (Zejda 1991). Also the spatial segregation due to competition with yellow-necked mouse may lower bank vole population (Grüm \& Bujalska 2000; Horváth et al. 2012).

Yellow-necked mouse is a typical species of old forests with regular production of tree seeds. Good seed crop can strongly influence its abundance (Obrtel \& Holišová 1974; Suchomel \& Heroldová 2008; Bjedov et al. 2016). In our study good acorn crop was in the first period in 1969 in the second in 1982 and 1983, in the third in 2003. Oak growth covers $86 \%$ of the study area, of which $90 \%$ are fruit-bearing trees. The influence of the seed years on overall small mammal dominance seems to be balanced.

Wood mouse eats greater variety of fruits and seeds, particularly seeds of shrubs, herbs, and grasses and for that ubiquitous species, changes in the phytocoenosis at the time when flooding period stopped (1982-1984) meant improvement in its trophic base (Obrtel \& Holišová 1974). Wood mouse decline in the last study period may be influenced by the increased dominance of yellow-necked mouse, which is a typical old forest species (Hoffmeyer \& Hansson 1974).

Results presented in this article indicate that changes in the MR can lead to changes in the dominance of selected species of small terrestrial mammals. These changes induce the chain of other changes related to important properties of the floodplain forest ecosystem, which markedly influence assemblages of small terrestrial mammals. For example also its diversity on our plots continually decreased in time. From $\mathrm{H}^{\prime}=1.04$ in flooded lowland (1968-72) to $\mathrm{H}^{\prime}=0.87$ in last research period (2002-2006; Zejda 1991; Suchomel \& Heroldová 2004). By Crandall et al. (2003) flooding may increase the diversity of mobile vertebrates in affected areas by providing and renewing resources as it increase the variety and abundance of food.

As human influences continue in our research area, ecological stability of the natural formations should be ensured. Long-term study on the influence of MR on small mammal species in natural lowland forests would be of help in further management. It can be also applied to the management of other similar forest ecosystems under moisture changes.

\section{ACKNOWLEDGMENTS}

\section{ZAHVALE}

This study was supported by financial means of the MSM 6215648902 and NAZV QH72075 projects. The work complied with Council directive 86/609/EEC regulations on experimental use of animals. English was improved by official SPI Publishing, professional editing services. The authors are very much obliged to Linda Bjedov for translation of English to Croatian.

\section{REFERENCES LITERATURA}

- Bjedov, L., P. Svoboda, A. Tadin, J. Habuš, Z. Štritof, N. Labaš, M. Vucelja, A. Markotić, N. Turk, J. Margaletić, 2016: Influence of beech mast on small rodent populations and hantaviruses prevalence in nacional park „Plitvice lakes“ and nature park „Medvednica“, Sumar list, 140: 455-464.

- Crandall, R. M., C. R. Hayes, E. N. Ackland, 2003: Application of the intermediate disturbance hypothesis to flooding, Community Ecol, 4: 225-232.

- Grüm, L., G. Bujalska, 2000: Bank voles and yellow-necked mice: What are interrelations between them?, Pol J Ecol, 48: 141-145.

- Hadaš, P., 2003: Temperature and humidity conditions of the floodplain forest with respect to stand microclimate and mesoclimate, Ekol Bratislava, 22: 19-46.

- Hoffmeyer, I., L. Hansson, 1974: Variability in number and distribution of Apodemus flavicollis and A. sylvaticus in South Sweden, Z Saugetierkd, 39: 15-23.

- Holišová, V., 1969: Vertical movements of some small mammals in a forest, Zool Listy, 18: 121-141.

- Holišová, V., 1971: The food of Clethrionomys glareolus at different population densities, Acta Sci Nat Brno, 5: 1-34.

- Horváth, G. F., D. Schäffer, A. Pogány, D. Töth, 2012: Spatial distribution of small mammal populations in Drava floodplain forests, Sumar list, 136: 141-151.

- Jacob, J., 2003: The response of small mammal populations to flooding, Mammal Biol, 68: 102-111. 
- Kolibáč, J., 1995: The diets of Sorex araneus and Sorex minutus in selected habitats in the Czech Republic, Acta Musei Mor Sci Nat, 80: 95-161.

- Křístek, J., 1991: Selected groups of insects and harvestman. In: Penka, M., Vyskot, M., Klimo, E., Vašíček, F., (eds.), Floodplain forest ecosystem II: After Water Management Measures, Academia, Prague, pp. 451-468.

- Moran, M. S., D. P. C. Peters, M. P. McClaran, M. H. Nichols, M. B. Adams, 2008: Long-term data collection at USDA experimental sites for studies of ecohydrology, Ecohydrology, 1: 377-393.

- Možný, M., 1993: Potential evapotranspiration as an important agro-climatic characteristic (in Czech), Meteorologické zprávy, 46: $152-156$

- Nosek, M., 1972: Metody v klimatologii., Academia, 433 p., Praha.

- Obrtel, R., V. Holišová, 1974: Trophic niches of Apodemus flavicollis and Clethrionomys glareolus in lowland forest, Acta Sci Nat Brno, 8: 1-37.

- Odum, E. P., 1977: Základy ekologie, Academia, 733 p., Praha.

- Pachinger, K., 1982: Quantitative Verhältnisse in der Population der Kleinsäuger im Sumpfmoor-Erlendwald der Reservation Jurský Šúr, Biologia Bratislava, 37: 1019-1026.

- Pachinger, K., J. Haferkorn, 1998: Comparisons of the small mammal communities in floodplain forests at the Danube and Elbe rivers, Ekol Bratislava, 17: 11-19.

- Penka, M., M. Vyskot, E. Klimo, F. Vašíček, (eds.), 1985: Floodplain forest ecosystem I. Before Water Management Measures, Academia, 466 p., Praha.

- Penka, M., M. Vyskot, E. Klimo, F. Vašíček, (eds.), 1991: Floodplain forest ecosystem II. After Water Management Measures, Academia, 629 p., Praha.

- Suchomel, J., M. Heroldová, 2004: Small terrestrial mammals in two types of forest complexes in intensively managed landscape of South Moravia (The Czech Republic), Ekol Bratislava, 23: $377-384$

- Suchomel, J., M. Heroldová, 2008: Effect of seed crop of trees on the abundance and body parameters of granivorous small mammals in isolated forest stands of southern Moravia (Czech Republic), Pol J Ecol, 56: 155-160.

- Suchomel, J., L. Purchart, L. Čepelka, 2012: Structure and diversity of small-mammal communities of lowland forests in the rural central European landscape, Eur J Forest Res, 131: 1933-1941.

- Vaňhara, J., 1986: Impact of man-made moisture changes in floodplain forest Diptera, Acta Sci Nat Brno, 10: 1-39.

- Vašíček, F., 1991: The impact of water withdrawal in the floodplain forest, in: Penka, M., M. Vyskot, E. Klimo, F. Vašíček, (eds.), Floodplain forest ecosystem II: After Water Management Measures, Academia, Prague, pp. 65-68.

- Vašíček, F., J. Pivec, 1991: The meteorological conditions in southern Moravia following the control of flooding in the floodplain forests, in: Penka, M., M. Vyskot, E. Klimo, F. Vašíček, (eds.), Floodplain forest ecosystem II: After Water Management Measures, Academia, Prague, pp. 75-80.

- Wijnhoven, S., G. van der Velde, R. S. E. W. Leuven, A. J. M. Smits, 2005: The importance of geomorphological and vegetational heterogeneity in river floodplain, Acta Theriol, 50: 453-472.

- Wijnhoven, S., G. van der Velde, R. S. E. W. Leuven, A. J. M. Smits, 2006: Modeling recolonisation of heterogeneous river floodplains by small mammals, Hydrobiologia, 565: 132-152.

- Zejda, J., 1976: The small mammal community of a lowland forest, Acta Sci Nat Brno, 10: 1-39.

- Zejda, J., 1985: Energy flow through the small mammal community of a floodplain forest. In: Penka, M., M. Vyskot, E. Klimo, F. Vašíček, (eds.), Floodplain forest ecosystem I. Before Water Management Measures, Academia, Prague, pp. 357-371.

- Zejda. J., 1991: A community of small terrestrial mammals, in: Penka, M., M. Vyskot, E. Klimo, F. Vašíček, (eds.), Floodplain forest ecosystem II: After Water Management Measures, Academia, Prague, pp. 505-521.

- Zhang, M., K. Wang, Y. Wang, C. Guo, B. Li, C. Huang, 2007: Recovery of rodent community in an agroecosystems after flooding, J Zool, 272: 137-148.

\section{Sažetak}

Promjene režima vlažnosti i njegovog utjecaja na zastupljenost određenih vrsta sitnih sisavaca, praćeni su u poplavnim šumama u Južnoj Moravskoj (rijeka Dyje). U razdoblju od 1968. do 1972. godine u vrijeme tipičnih poplavnih režima karakteriziranih fluktuacijama razine podzemne vode (s visokom razinom podzemne vode ili poplavama u proljeće) zastupljenost žutogrlog šumskog miša (Apodemus flavicollis /Mel./) bila je $42 \%$, šumske voluharice (Myodes glareolus /Schreb./) 33 \% i šumske rovke (Sorex araneus L.) $15 \%$. U razdoblju od 1982. do1987. godine nakon prestanka poplava regulacijom rijeke te naglog pada podzemne vode i promjena u prizemnoj vegetaciji, zastupljenost žutogrlog šumskog miša i šumske voluharice se povećala. Također je porasla i zastupljenost šumskog miša (Apodemus sylvaticus /L./), dok se zastupljenost šumske rovke srušila. Daljnji zahvati revitalizacije vodnog režima su primijenjeni uvođenjem kanala koji su vodom opskrbljivali korijenje drveća, ali ne i prizemnu vegetaciju. Od 2002. do 2006. godine opadanje vlažnosti dalje je pogodovalo porastu dominacije žutogrlog šumskog miša dosegnuvši $62 \%$. Zastupljenost šumske voluharice smanjuje se na $20 \%$, dok brojnost šumske rovke ostaje niska. Sve dobivene promjene zastupljenosti sitnih glodavaca su u signifikantnoj korelaciji s režimom vlažnosti. Iz navedenog proizlazi da promjene režima vlažnosti u šumi signifikantno utječu na zajednicu sitnih sisavaca.

KLJUČNE RIJEČI: poplavne šume, rezervat biosfere, režim vlage, sitni sisavci, zastupljenost 